\title{
The use of interactive whiteboard (IWB) by pre-service teachers to enhance Arabic language teaching and learning
}

\author{
Fawzi Fayez Ishtaiwa \\ Zuhrieh Shana \\ Al Ain University of Science and Technology, UAE
}

\section{Introduction}

There is no doubt that technology-enhanced education is becoming an increasingly important component of teaching and learning languages as well as other subjects. The use of modern technology applications (e.g. multimedia CD ROMs, videoconferencing, asynchronous tutorials, speech recognition, speech synthesis, e-mail groups, learner monitoring, electronic libraries and on-line testing) affect the techniques we learn and use to teach languages (Chen, Belkada \& Okamoto, 2004; Kern, 2006). In fact, digital technology has played an important role in facilitating the ways in which information can be delivered and shared, not just from teacher to learner, but also among learners themselves.

A significant number of researchers have investigated the impact of the use of technology in language teaching and learning in different settings and contexts, and most of these studies agree that the use of technology in language teaching and learning can bring improvements in students' achievement (Almekhalifi, 2006; Lee, 2000; Mansor, 2007; Timucin, 2006). According to Lee (2000), computers and software have numerous benefits for the teaching and learning process. Such benefits include (a) improving student's practices through experimental learning, (b) enhancing student's learning motivation, (c) improving student's achievement, (d) creating more authentic activities and materials, (e) encouraging greater interaction between teachers and students and among students themselves, (f) emphasizing student's individual needs, and (g) enlarging global understanding.

Technologies have the potential to revolutionize the teaching and learning process, offering students opportunities to learn in new ways (Crystal, 2001). One examples is the interactive whiteboard (IWB) - a large, touch-sensitive screen that works in conjunction with a computers and projector - which has the potential to improve teaching and learning experiences by offering useful ways for students to interact with electronic content (Campbell, 2010).

IWB provides a variety of benefits that include: (1) replicating the functions of older presentation technologies such as flipcharts, overheads, slide projectors and videos; (2) facilitating the manipulation of text and images for the class; (3) allowing creative and dynamic integration of Web-based materials; (4) providing indefinite storage space, quick retrieval of materials and immediate feedback; (5) viewing content as a group; (6) using software in classroom without being tied to a computer; (7) creating digital lesson activities with templates, images and multimedia; (8) writing notes over educational video clips; (9) and using presentation tools that are included in the software to enhance learning materials (Kennewell, 2006; Schuck \& Kearney, 2007).

Virtually anything that can be done on a computer can be done on IWB; it can be used to deliver instruction in various ways including visual and auditory learning. While the visual learning includes the use of text, pictures, animation, and video, the auditory involves the use of words orally for

Ishtaiwa, F.F. \& Shana, Z. (2011). The use of interactive whiteboard (IWB) by pre-service teachers to enhance Arabic language teaching and learning. Learning and Teaching in Higher Education: Gulf Perspectives, 8(2). 
pronunciation, speeches, and poems. In addition, IWB allows students to physically interact with the board (Swan, Schenker, \& Kratcoski, 2008).

Earlier research literature on the use of IWB's in both K-12 and higher education shows promising results, where several studies indicated that the use of IWB increases enjoyment, engagement, motivation, and learning gains for all ages and across all areas of the curriculum (Kennewell, 2001; Levy, 2002; Smith, 2000; Smith, Hardman \& Higgins, 2006). Levy (2002) argues that IWB's motivate students to answer teachers' questions due to the strong visual and conceptual appeal of the information that is displayed, and because of the way they allow students to physically interact with the board in search of those answers. In addition, there is some evidence that the use of interactive whiteboards can increase student achievement (Dhindsa \& Emran, 2006; Swan, Schenker \& Kratcoski, 2008; Zittle, 2004).

Based on the previous review, it is evident that integrating IWB technology into the teaching system can provide motivational outcomes; however, this integration involves a number of challenges. Simply having a large electronic workspace does not necessarily achieve the desired results in term of improving teaching and learning. It is important to note that there are issues associated with teachers using IWB which need to be addressed as a first step for effective technology integration. Utilizing IWB effectively requires an investment of time, appropriate technical and pedagogical training, independent exploration by teachers, feeling confident in using IWB, understanding the technical issues, reliable infrastructure and network connections, as well as a requirement for teachers to create a range of multimedia teaching materials and understanding that this process can be quite time consuming (Campbell, 2010).

In addition, it is important to keep in mind that efforts to integration technology effectively are of little value if they do not take into account teachers' level of experience. The research literature suggests that the success or failure of institutions integrating techniques depends largely on the teachers' perceptions of technology, and their willingness to implement it in their teaching (Ajayi, 2009; Fulton, Glenn \& Valdez, 2004; Ishtaiwa, 2010; Johnson, 2007). Schellens, Van Keer \& Valcke (2005), indicate that an individual's perception of a learning task defines the challenge, difficulty, and balance of motivation necessary to address it. In this regard, Molebash (2004) argues that the perceptions of new teachers influence their teaching of specific subjects and their decisions about integrating technologies.

Given the lack of sufficient evidence to support some of the assertions made about the benefits of IWB in promoting language teaching and learning, this study is carried out to investigate the use of IWB by Arabic language pre-service teachers, and to examine their perceptions of its impact on teaching and learning Arabic as a case study.

\section{Purpose and significance of the study}

There has been a notable amount of research examining the issue of integrating modern technology into English language classes in different contexts and at different levels. However, the research literature is limited in the area of integrating technology in Arabic language classes. This study was conducted to analyze pre-service school teachers' use of a relatively new technology, the Interactive Whiteboard (IWB), and to examine their perceptions of the impact of using such technology in teaching and learning Arabic during their teaching practice sessions in UAE schools.

Understanding the perceptions of pre-service teachers of their own learning while implementing technology will help researchers and educators to gain insights into the connection between the theory and practice of using technology to promote learning (Johnson, 2007). Therefore, in contributing to the

Ishtaiwa, F.F. \& Shana, Z. (2011). The use of interactive whiteboard (IWB) by pre-service teachers to enhance Arabic language teaching and learning. Learning and Teaching in Higher Education: Gulf Perspectives, 8(2). 
body of the IWB research literature, this study is expected to advance researchers', educators' and legislators' understanding of how digital technology is used in education, and to help them in establishing a learning environment that will promote effective use of existing technology.

\section{Research Questions}

1. How do pre-service teachers perceive their competencies in integrating digital technology in teaching Arabic?

2. What are pre-service teachers' views of IWB as a teaching and learning tool for Arabic?

3. How do pre-service teachers of Arabic use the IWB in their teaching?

4. What are the challenges of using IWB perceived by pre-service teachers of Arabic?

\section{Literature review}

The increasing level of utilizing technology in $\mathrm{K}-12$ classrooms has motivated numerous researchers to explore the big question of whether technology in general can improve language teaching and learning (AlMekhalifi, 2006; Ismail, Almekhlafi \& Al-Mekhlafy, 2010; Lee, 2000; Mansor, 2007; Timucin, 2006). However, more important questions present themselves: can particular technologies be used in particular learning contexts for achieving particular learning outcomes? And what are the existing factors that help or hinder the learning process? (Winzenried, Dalgarno \& Tinkler, 2010). Consistent with this more complex view of the role of technology in the teaching and learning process, a number of studies have focused on specific issues associated with teaching and learning practice involving IWB as one of the newest technologies entering schools at an increasing rate.

In general, teaching and learning activities with IWB may include the following (Březinova, 2009; Brown, 2009; Swan, Schenker, \& Kratcoski, 2008):

- Motivating teachers to incorporate and develop more digital resources such as video clips, films, sounds, songs, interviews, electronic microscopes, instructional games, online interactive websites etc.

- Enabling teachers to write, highlight, edit on-screen and save changes for further use; this makes it easier to build a collection of learning materials that can be regularly updated.

- Motivating students by allowing them to come to the front of the class and demonstrate their knowledge by completing a diagram, a sentence, a picture, etc.

- Viewing and browsing the Internet from the whiteboard, allowing all students to see and interact with visited websites in a teacher-guided manner.

- Providing an electronic flipchart, with all notes and diagrams saved as an HTML file for later use (e.g. for printing).

- Promoting collaborative learning by allowing students to add their contribution to the discussion by writing directly on the whiteboard. In addition, groups can view and solve interactive problems

- Demonstrating how educational software works.

Ishtaiwa, F.F. \& Shana, Z. (2011). The use of interactive whiteboard (IWB) by pre-service teachers to enhance Arabic language teaching and learning. Learning and Teaching in Higher Education: Gulf Perspectives, 8(2). 
- In a networked environment, allowing teachers to monitor each student and choose which screen is displayed on the whiteboard.

- Catering more effectively for students with special needs, for example by using the large fonts and bright colors to help those who have trouble staying on task.

- Running online tests and displaying instant feedback to the group.

Initial literature related to IWB tended to examine case studies of using IWBs in particular classes, concentrating on the capabilities and benefits of the device, and on teachers and/or students' perspectives (Březinova, 2009; Campbell, 2010; Dhindsa \& Emran, 2006; Hall \& Higgins, 2005; Swan, Schenker \& Kratcoski, 2008; Schuck \& Kearney, 2007; Winzenried, Dalgarno \& Tinkler, 2010; Zittle, 2004). In terms of IWB capabilities, one of the main characteristics of IWB is its power to promote an 'interactive' class, as indicated by Levy (2002), who reported that IWB motivated students to participate in classroom activities due to the strong visual and conceptual appeal of the displayed information, and the way IWB allows them to physically interact with the board. Students in the study indicated that sharing their work with others in the class helped them to articulate their ideas and give explanations. Furthermore, they reported that they also enjoyed the opportunity of seeing and discussing others' work.

Similarly, in its review of the literature, the British Educational Communications and Technology Agency (BECTA) state that the key benefits of IWB as a tool of pedagogy that it "encourages more varied, creative and seamless use of teaching materials; increases students' engagement, enjoyment, and motivation to a greater extent than conventional whole-class teaching; and facilitates students' participation through the ability to interact with materials on the board" (BECTA, 2003, p. 1). In addition, there is some evidence that the use of IWB can influence students' achievement (Dhindsa \& Emran, 2006; Swan, Schenker \& Kratcoski, 2008; Zittle, 2004). For example, Dhindsa \& Emran (2006) explored the effects of IWB on organic chemistry achievement by comparing test gains of six college classes taught either with or without IWBs. Student achievement was evaluated using a test consisting of sections on multiple choice, short answers and essay type questions. The results of the study revealed that the mean gain in achievement score for an IWB group compared to the traditional group was statistically significantly higher on the total test as well as on the sections of the test.

In another study, Swan, Schenker \& Kratcoski (2008) examined the impact of using IWB on reading/language arts and mathematics achievement test scores of all students in grades 3-8. The study compared scores on state achievement tests of all students whose teachers used IWBs for instruction and those whose teachers did not. The findings showed slightly higher performance among students in the IWB group. Indeed, greatest results were demonstrated at the fourth and fifth grade levels and significant interactions between achievement gains and grade levels were found in both mathematics and reading/language arts.

Regarding teachers' perspectives on IWB as a teaching tool, Gray et al. (2005) investigated language teachers' perspectives of integrating IWB into their instruction practice. Participants reported that use of IWB enhances teaching greatly by supporting classroom management, pace and variety and drawing attention to the grammatical features and patterns. Participants also felt that use of the IWB had very positive effects on students' memorization skills and writing development.

Winzenried, Dalgarno and Tinkler (2010) examined teachers' perspectives on the impact of IWB's on classroom teaching practice. Using intensive case studies focusing on six primary and secondary teachers, the study found that all teachers were enthusiastic, witnessed improvements in students'

Ishtaiwa, F.F. \& Shana, Z. (2011). The use of interactive whiteboard (IWB) by pre-service teachers to enhance Arabic language teaching and learning. Learning and Teaching in Higher Education: Gulf Perspectives, 8(2). 
engagement, and were able to develop and evolve their IWB teaching strategies through explicit reflection. However, the study noted that there were considerable differences in the ways IWB was used and the degree which they changed classroom teaching practices.

Along with these findings, it is important to keep in mind that placing IWBs in schools is not sufficient in order to meet their positive outcomes. Getting the benefits of technology in teaching and learning depends on a combination of reliable technology, teachers' skills, and the variety of approaches they use. The research literature suggested that certain problems associated with the use of IWBs may hinder the effective use of such innovation. They are: teachers' lack of appropriate training in effective integration, lack of teachers' time to attend training and prepare materials, lack of teachers' interest in using technology, and the possibility of limited student interaction with the prepared materials (Březinova, 2009; Campbell, 2010).

In this regard, Glover and Miller (2001) have argued that the teacher and his attitude towards technology play a vital role in effective technology integration. They identified the following three types of teachers with different attitudes towards the adoption of IWB's:

1. "Missioners" - those who are interested in new technologies, use them on regular basis in their teaching and try to convince others to use them too.

2. "Tentatives" - those who underwent some training, have access to rooms with IWB but are somehow afraid of them.

3. "Luddites" - those are the technophobes who underwent training, but are afraid of everything new and do not want to waste their time and energy.

In a later study, Glover and Miller concluded that in order to realize the potential benefits of IWB, a number of conditions related to the teacher's attitude had to be met: "(a) there was a will to develop and use the technology; (b) the teachers had to be willing to become mutually interdependent in the development of materials; and (c) there had to be some change of thinking about the way in which classroom activities were resourced" (Glover \& Miller, 2002, p.5).

Based on this literature review, it is evident that IWB has the potential to make a major impact on learning and teaching at all educational levels. However, it is critical to know how this positive impact can best be realized and achieved in a particular subject matter and context. Pre-service teachers, who are the teachers of the future, can provide valuable insights by describing their use and perceptions of the impact of IWB on their classroom instruction. Therefore, this study aimed to shed some light on the use and impact of IWB as a tool for such teachers in teaching and learning the Arabic language.

\section{Methodology}

\section{Research context and participants}

The site of the study was Al Ain University of Science and Technology (AU) in the United Arab Emirates (UAE). Like other universities worldwide, $A U$ is involved in an educational renewal effort to promote the effective use of digital technologies in each of its programs of study. The study was conducted at the Faculty of Education as a case study following encouragement from the university administration to incorporate technology in the teaching and learning process. The Faculty of Education offers three educational programs (English Language Teacher Education, Information Technology Teacher Education, and Professional Diploma in Teaching) designed to prepare teachers and educational leaders as well as

Ishtaiwa, F.F. \& Shana, Z. (2011). The use of interactive whiteboard (IWB) by pre-service teachers to enhance Arabic language teaching and learning. Learning and Teaching in Higher Education: Gulf Perspectives, 8(2). 
to advance the profession of education through emphasis on active learning through research, technology, clinical processes and collaboration with local schools and educational institutions in the UAE.

In particular, the program of Professional Diploma in Teaching aims to help teachers who have a BA or BSc from Faculty other than the Faculty of Education to obtain professional preparation. This goal is in congruent with the Ministry of Education directions that all teachers should have professional preparation. As a part of the program, students take a practical semester ( 6 credit hours) before their graduation. The purpose of this practicum is to expose pre-service teachers to the realities of school teaching, and to provide them with an opportunity to reflect on the relationship between educational theory and pedagogical practice. Their responsibilities include tutoring, working with individual students, working with small groups, preparing lesson plans, and presenting several lessons to the entire class. In this context, pre-service teachers are expected to better understand the importance of integrating technology in their instruction. They should learn to select, prepare, and use the appropriate technology as a tool to achieve better teaching and learning.

Because of the concentration on the use of IWB in Arabic language classes, pre-service Arabic language teachers registered in the Professional Diploma in Teaching program were included in the study. Thus, the population of the study consisted of 293 practicum students registered in the second semester of 2009/ 2010 academic year; all of these student teachers were from Oman and Arabic is their first language. Of these 293 pre-service Arabic teachers, 236 (80.5\%) were females, and 57(19.5\%) were males. They conducted their practicum semester in 79 public and private schools distributed in four cities in the UAE (Abu Dhabi, Al Ain, Fujairah, and Sharjah). While all pre-service Arabic language teachers were asked to fill out the questionnaire used in this study, twelve participants ( 3 males and 9 females) were selected randomly to be interviewed.

In sampling participants for the interviews, pre-service Arabic language teachers were personally contacted by the researchers to request participation. When some pre-service teachers did not agree to participate, others were randomly selected to be involved in the study.

\section{Instruments}

A combination of quantitative and qualitative approaches was used to collect data needed to answer the research questions. The instruments comprised a questionnaire and semi- structured interviews; the questionnaire consisted of five major sections:

(1) demographic information;

(2) individual technological applications competency;

(3) views of IWB as a teaching and learning tool;

(4) use of IWB;

(5) views regarding challenges and barriers that hinder the use of IWB.

The questionnaire was developed based on the literature review, the research questions, and the researchers' experience in the field.

Once the initial questionnaire was developed, it was validated in two stages. In the first stage, the questionnaire was submitted to a panel of experts in the field of curriculum and instruction, instructional technology, research and evaluation, and to Arabic subject supervisors. They were asked to judge the items of the questionnaire for their adequacy to the research questions. The panel of experts was also asked to assess (1) the clarity in the directions and the question, (2) the continuity across

Ishtaiwa, F.F. \& Shana, Z. (2011). The use of interactive whiteboard (IWB) by pre-service teachers to enhance Arabic language teaching and learning. Learning and Teaching in Higher Education: Gulf Perspectives, 8(2). 
sections of the survey, (3) the amount of time needed to complete the questionnaire; and they were asked to recommend additions or deletions of items and variables to the questionnaire. Based on this process of validation, three items were rewritten, two items were added, and one item was deleted. In the second stage of validating the questionnaire, it was translated by the researchers into Arabic (the first language of the participants). The Arabic version was reviewed by a panel consisting of Arabicspeaking instructors of Arabic and English languages. The purpose of this process was to ensure the accuracy of the Arabic translation. A few minor changes were suggested by these reviewers and incorporated into the questionnaire.

To examine the reliability of the questionnaire, it was piloted with a random sample of 45 pre-service Arabic teachers. They were asked to complete the questionnaire, make comments on its general quality, and identify specific questions that they found confusing or misleading. The statistical reliability of the instrument was assessed using Cronbach's alpha coefficient of internal consistency for the questionnaire with the data collected. The Cronbach Alpha value for the questionnaire has been calculated as 0.92 , which according to Muijs (2004) is a high value. After the previous pilot, one item was rewritten based on the comments of the participants.

The semi-structured interviews were employed to obtain in-depth perspectives, along with personal stories and contexts of the participants. The interview questions dealt with the following areas of inquiry:

(1) Individual competency in integrating digital technology in teaching Arabic,

(2) Views of IWB as a teaching and learning tool for Arabic,

(3) Use of IWB in the participants' own teaching,

(4) Views regarding challenges that hinder the use of IWB.

Once the initial questions were developed, they were submitted to a panel of experts to judge their quality and adequacy for matching the themes of the questionnaire and producing supportive data. Based on that review, two questions were rewritten and one item was added. In addition, the first researcher piloted the interview with three students who were not participants in the actual study. Questions and comments raised during these pilot interviews helped the researcher to further clarify the intentions of the study, and the wording of the questions. This process was valuable in insuring that the interview questions were comprehensible, and would generate data congruent with the purposes of the study.

\section{Data Collection}

In terms of the quantitative data, during the last two weeks of the second semester of 2009/2010 academic year, 293 questionnaires were distributed by seven research assistants to all pre-service Arabic language teachers in their schools. Pre-service teachers were requested to complete the questionnaire, place it in the enclosed envelope, and give it back to the research assistant or deposit the envelope in the mail boxes of the researchers. Before the end of the semester and to increase the number of teachers who responded to the questionnaire, all potential participants were sent a letter of thanks and a letter to remind them of the importance of their participation. The letter included another copy of the questionnaire packet in case the pre-service teacher had not responded yet. The number of questionnaires completed and returned was 179 , i.e. $61 \%$ overall response rate.

To collect the qualitative data, the researchers conducted semi-structured interviews with 12 selected participants who indicated that they integrated IWB in their Arabic language over 16 weeks of practicum sessions. The interviews took place in the first researcher's office at the end of the semester. Each

Ishtaiwa, F.F. \& Shana, Z. (2011). The use of interactive whiteboard (IWB) by pre-service teachers to enhance Arabic language teaching and learning. Learning and Teaching in Higher Education: Gulf Perspectives, 8(2). 
participant was interviewed in Arabic for 30-55 minutes. The interviews for all participants were audio taped and transcribed.

\section{Data Analysis}

The data from questionnaires were analyzed using SPSS to obtain relevant descriptive statistics. To analyze the data drawn from interviews, data analysis guidelines offered by Miles and Huberman (1994) were used. These guidelines include creating codes for the field notes, noting any reflections or remarks in the margins, creating codes for identifying similar patterns, themes, and common sequences in the data set, and creating a set of generalizations that derive from the available data. Additionally, the researchers performed data reduction by eliminating all information that was not relevant to the research questions, summarizing ideas, categorizing similar patterns, and paraphrasing stories (Miles \& Huberman, 1994).

\section{Results and discussion}

This study examined pre-service teachers' perceptions of IWB as a tool for improving Arabic language teaching and learning with reference to four research questions. Therefore, results and discussion of the general themes that emerged from data analysis are presented according to these questions. To answer the first research question regarding pre-service teachers' perceptions of their competencies in integrating digital technology in teaching Arabic, 179 participants were asked to rate their level of competencies in integrating a number of technological applications.

The rating scale included: don't use (0) beginner (1), intermediate (2), advanced (3), and expert (4). Data revealed that participants rated themselves higher at some skills than at others. The mean scores of participants ranged between 1.53 and 2.60. For example, participants rated their own skills in using MS Word to create materials higher than any other application, with $55.3 \%$ describing their skills as "advanced" or "expert". Responses also indicated that over $51 \%$ of participants placed themselves in the advanced or expert categories in using multimedia software (e.g. PowerPoint) to enhance presentations. However, only $11-25 \%$ of participants rated their skills as advanced or expert in using computers to assist students with special needs, using IWB, and integrating language labs to enhance students' learning. A complete description of these responses is reported in Table 1.

Table 1: Participants' responses of categorical competencies in descending rank order of means. ( $N=179)$

\begin{tabular}{|l|c|c|c|c|c|c|}
\hline Application & $\mathbf{0}$ & $\mathbf{1}$ & $\mathbf{2}$ & $\mathbf{3}$ & $\mathbf{4}$ & Mean \\
\hline Use MS Word to create materials & 0.55 & 8.37 & 35.75 & 40.22 & 15.08 & $\mathbf{2 . 6 0}$ \\
\hline $\begin{array}{l}\text { Use Multimedia software (e.g. PowerPoint) to } \\
\text { enhance presentations }\end{array}$ & 1.11 & 13.96 & 33.51 & 39.10 & 12.29 & $\mathbf{2 . 4 7}$ \\
\hline Use computers for on-line communication & 1.67 & 11.17 & 39.66 & 36.87 & 10.61 & $\mathbf{2 . 4 3}$ \\
\hline $\begin{array}{l}\text { Use audio clips software to enhance students' } \\
\text { learning }\end{array}$ & 1.11 & 20.11 & 37.98 & 30.16 & 10.61 & $\mathbf{2 . 2 9}$ \\
\hline $\begin{array}{l}\text { Use devices such as scanners, digital cameras, } \\
\text { and/or video cameras. }\end{array}$ & 0.55 & 18.43 & 38.54 & 37.98 & 4.46 & $\mathbf{2 . 2 7}$ \\
\hline Use video clips software to enhance students' & 1.11 & 17.31 & 45.25 & 30.16 & 6.14 & $\mathbf{2 . 2 2}$ \\
\hline
\end{tabular}

Ishtaiwa, F.F. \& Shana, Z. (2011). The use of interactive whiteboard (IWB) by pre-service teachers to enhance Arabic language teaching and learning. Learning and Teaching in Higher Education: Gulf Perspectives, 8(2). 


\begin{tabular}{|c|c|c|c|c|c|c|}
\hline learning & & & & & & \\
\hline $\begin{array}{l}\text { Use a database software to set up and access } \\
\text { information }\end{array}$ & 3.35 & 20.11 & 40.22 & 27.37 & 8.93 & 2.18 \\
\hline Use spreadsheets to create charts and graphs & 2.23 & 24.58 & 41.34 & 27.37 & 4.46 & 2.07 \\
\hline $\begin{array}{l}\text { Use graphic software to create illustrations, slides, } \\
\text { or images. }\end{array}$ & 3.35 & 23.46 & 42.45 & 25.69 & 5.02 & 2.05 \\
\hline $\begin{array}{l}\text { Use computer programs related to language } \\
\text { teaching and learning }\end{array}$ & 3.91 & 21.78 & 45.81 & 24.02 & 4.46 & 2.02 \\
\hline Use social networks (e.g., Blogs, Wikis, Face book). & 3.35 & 26.25 & 40.78 & 24.58 & 5.02 & 2.01 \\
\hline Utilizing computers to assess students learning. & 2.79 & 26.81 & 44.13 & 24.02 & 2.23 & 1.95 \\
\hline Use computers to assist students with special needs. & 3.91 & 28.49 & 42.45 & 21.78 & 3.35 & 1.91 \\
\hline Use Interactive White Board. & 6.70 & 35.75 & 41.34 & 12.84 & 3.35 & 1.70 \\
\hline $\begin{array}{l}\text { Integrating language labs to enhance students' } \\
\text { learning }\end{array}$ & 7.82 & 43.01 & 38.54 & 8.93 & 1.67 & 1.53 \\
\hline
\end{tabular}

This means that these teachers vary in their capabilities and skills in integrating different types of technology in their teaching. This finding was supported by interview data; for example, a participant mentioned that:

I'm very good in integrating different types of technology in my classroom. I consider myself as an expert in using the Microsoft Word, PowerPoint, and the internet to get information or communicate with others. In addition I love to use Facebook and other social media. I do have my own educational blog. In many cases, I teach my colleagues how to use some technological applications. At the same time, to be honest, I never used the language lab.

Another participant stated that

Because I do believe in the value of technology for teaching and learning Arabic, I always try to integrate it in my teaching. I use the computer to create learning materials, assess students' learning, and present audio and video clips. But I still need a lot of help in doing that more effectively. I'm a beginner user or in best cases, I'm an intermediate computer user.

It can be concluded that the degree of technology integration in teaching Arabic depends on the degree of technology competency and expertise that pre-service teachers possess. A participant noted that

I favored integrating Microsoft Word and Microsoft PowerPoint in my teaching because I'm comfortable in using these softwares.

while another said that

I do not feel comfortable using the computer in front of my students because I do not have sufficient skills to do so. I really do not know, so I hate the computer or I fear of using it

A similar finding was reported in a study conducted by Lam (2000), where he found out that teachers usually integrate more technology in their teaching when they possess higher levels of technology proficiency. Such finding clearly shows the urgent need to provide pre-service teachers with adequate skills of technology integration.

Ishtaiwa, F.F. \& Shana, Z. (2011). The use of interactive whiteboard (IWB) by pre-service teachers to enhance Arabic language teaching and learning. Learning and Teaching in Higher Education: Gulf Perspectives, 8(2). 
To answer the second research question regarding pre-service teachers' views of IWB as a teaching and learning tool of Arabic, participants were asked to indicate whether thy have utilized IWB in their Arabic language teaching or not. The responses show that only 26 (14.5\%) participants have used IWB for Arabic teaching and learning purposes. These 26 IWB users were asked to evaluate the effectiveness of using IWB to enhance teaching and learning of Arabic. Data collected from participants' questionnaires revealed that all pre-service Arabic teachers who used IWB held high positive views toward IWB use. The overall mean of users' responses for each possible advantage of IWB use ranged from 3.61 to 4.84 on a 5 point scale.

The top five benefits of IWB identified by IWB users were: (1) providing variety of information and learning resources; (2) making teaching Arabic easier; (3) helping teachers to give more effective explanations; (4) saving time and enabling lessons to move more quickly; and (5) help to meet students' different language needs. These findings are displayed in Table 2 in descending rank order of means.

Table 2: Users' attitudes toward IWB Use in descending rank order of means. $(\mathbf{N}=\mathbf{2 6})$

\begin{tabular}{|l|c|c|}
\hline IWB is a tool that.... & Mean & SD \\
\hline provides variety of information and learning resources & 4.84 & 0.46 \\
\hline makes teaching Arabic easier & 4.80 & 0.49 \\
\hline helps me to give more effective explanations & 4.69 & 0.67 \\
\hline saves time and enables lessons to move more quickly & 4.50 & 0.86 \\
\hline help to meet students' different language needs & 4.42 & 0.64 \\
\hline increases time for language task-related activities & 4.43 & 0.68 \\
\hline encourages students to pay more attention & 4.26 & 0.66 \\
\hline improves students' academic achievement and grades & 4.23 & 0.99 \\
\hline makes learning Arabic easier and faster & 4.15 & 0.78 \\
\hline makes learning Arabic more enjoyable and more interesting & 4.11 & 0.90 \\
\hline increases learners' motivation & 4.03 & 0.82 \\
\hline provides opportunities for using different strategies in learning Arabic & 4.03 & 0.99 \\
\hline provides a stimulus for teacher-student interaction & 4.00 & 0.74 \\
\hline improves students' language skills & 3.96 & 0.82 \\
\hline promotes cooperative activities during Arabic learning & 3.92 & 0.89 \\
\hline allows me to save generated material and re use it & 3.61 & 0.89 \\
\hline
\end{tabular}

This finding was also evident in the interviewed pre-service teachers' typical responses. For example, as one explained:

By using IWB, every student can see what I'm exactly presenting; In addition, my students can see where to go and what they need to do. It allows me to present my lessons easily and fast, thus giving

Ishtaiwa, F.F. \& Shana, Z. (2011). The use of interactive whiteboard (IWB) by pre-service teachers to enhance Arabic language teaching and learning. Learning and Teaching in Higher Education: Gulf Perspectives, 8(2). 
more time to see what the students are doing and provide them with immediate feedback on their work.

\section{Another participant said that}

There are a lot of things to mention when we talk about the benefits of IWB for my Arabic teaching. First of all, IWB allows me to access a lot of resources that make my lessons more fun, interesting, and interactive. Adding sound, video, and images also makes them entertaining. In addition, it helps me to address different student's learning needs. For example, I could split IWB into a number of screens to correspond to different levels of students' understanding.

While the benefit of saving and re-using generated materials was ranked the last according to the participants, most of the interviewees concentrated on this as one of the most important advantages of IWB. A pre-service teacher indicated:

IWB is a wonderful tool. Sometimes it makes my lesson successful when new ideas come to my mind. Without IWB, I had no way of saving my lesson but now I can do that and can use it in my future lessons.

The group of pre-service Arabic language teachers who have used IWB view it as a useful and beneficial tool for their classes. They seem to be enthusiastic about using IWB because it offers them a variety of instructional benefits. The study described how pre-service teachers see the potential importance of using IWB in teaching and learning of Arabic language. They agreed that IWB helped them to develop a better, faster, and more effective instruction. This finding was in agreement with the findings of other studies that found positive teacher reactions to the use of IWB. (Gray, et al., 2005; Dhindsa \& Emran, 2006; Levy, 2002; Swan, Schenker \& Kratcoski, 2008; Winzenried, Dalgarno and Tinkler, 2010; Zittle, 2004), but contrasted with other studies such as Gatlin's findings (2004) which reported initial resistance from some teachers to the use of IWB.

The third research question of this study was "How do pre-service teachers of Arabic use IWB in their teaching?" To answer this question, IWB users were asked to select from a list of purposes and activities what they use IWB for as a part of classroom instructions. Using IWB for presenting language information and materials for class was the most commonly application used. All users (100\%) reported using IWB as a tool to show information and resources.

The second most adopted use of IWB was to facilitate explanation of concepts and ideas. More than $88 \%$ of users indicated that they use IWB to help them give more effective illustration and explanation of their language topics. The next most frequently IWB use was enabling students to receive feedback and insert notes directly into the presentations. $73 \%$ of users emphasized that they used IWB to give immediate feedback across the class as a whole, and they also pointed out the value of being able to write directly on their prepared presentations and materials. In addition, more than half of IWB users reported using the tool to display handwriting more neatly, reduce time spent in writing, and enable students to present and discuss their work.

Other applications were apparently not much in use. Over $75 \%$ of users indicated that they did not use IWB to help students with special needs, respond creatively to students' questions or ideas, use the record feature to narrate the text, use the flip chart to address different students' needs, or encourage critical thinking using concept-mapping software like Inspiration or Kidspiration. These findings are summarized in Table 3 by purpose/activity, number, and percentage of participants citing each use.

Ishtaiwa, F.F. \& Shana, Z. (2011). The use of interactive whiteboard (IWB) by pre-service teachers to enhance Arabic language teaching and learning. Learning and Teaching in Higher Education: Gulf Perspectives, 8(2). 
Table 3: Number and percentage of participants by IWB use. ( $N=26)$

\begin{tabular}{|c|c|c|}
\hline IWB was used as a tool to... & Number & Percent \\
\hline present language information and materials for whole-class & 26 & $100 \%$ \\
\hline facilitate explanation of concepts and ideas & 23 & $88.5 \%$ \\
\hline enable students to receive feedback & 19 & $73 \%$ \\
\hline take notes directly into presentations & 19 & $73 \%$ \\
\hline display handwriting more neatly & 16 & $61.5 \%$ \\
\hline reduces time spent in writing & 16 & $61.5 \%$ \\
\hline enable students to present and discuss their work & 15 & $57.7 \%$ \\
\hline access different resources and a wider variety of formats & 12 & $46.2 \%$ \\
\hline save, print, and re use materials & 12 & $46.2 \%$ \\
\hline use the record feature to teach new vocabulary or poetry & 11 & $42.3 \%$ \\
\hline facilitate group discussion & 10 & $38.5 \%$ \\
\hline promote cooperative activities during learning activities & 10 & $38.5 \%$ \\
\hline facilitate participative whole-class learning & 10 & $38.5 \%$ \\
\hline evaluate students' learning & 9 & $34.6 \%$ \\
\hline $\begin{array}{l}\text { encourage students to use Internet to get language information and } \\
\text { materials independently }\end{array}$ & 7 & $26.9 \%$ \\
\hline show streamed or downloaded video clips & 7 & $26.9 \%$ \\
\hline help students with special needs & 6 & $23.1 \%$ \\
\hline Respond creatively to students' questions or ideas & 4 & $15.4 \%$ \\
\hline use the record feature to narrate the text & 3 & $11.5 \%$ \\
\hline use the flip chart to address different students' needs & 2 & $7.7 \%$ \\
\hline $\begin{array}{l}\text { encourage critical thinking using concept-mapping software like } \\
\text { Inspiration or Kidspiration. }\end{array}$ & 0 & $0 \%$ \\
\hline
\end{tabular}

The analysis of participants' responses on interview questions supported the previous finding. The following are some of the responses from four IWB users:

IWB helped me a lot in teaching Arabic. For instance, it is a powerful and great tool to present my materials in a different and new way. In addition, it is valuable in helping students present their work without touching the computer keyboard. Actually, my students and I like IWB for making our duties easier and more fun.

By utilizing IWB in my Arabic teaching, I'm a better teacher. Its major advantage is helping me give effective, clear illustration of concepts, ideas, and information I teach. For example, the opportunity to use the highlighter tool to highlight nouns, verbs, and adjectives is a great one.

Ishtaiwa, F.F. \& Shana, Z. (2011). The use of interactive whiteboard (IWB) by pre-service teachers to enhance Arabic language teaching and learning. Learning and Teaching in Higher Education: Gulf Perspectives, 8(2). 
I conduct many learning activities using IWB: presenting materials, attracting and stimulating all students' participation, giving feedback and commenting on students' work in a creative way. For example, if I mention something that my students do not know, I can use the internet right away to show them a picture or a movie clip of it.

At the same time of doing many things with IWB, there are a lot of features of IWB that I could not implement effectively. I hear about the benefit of using concept-mapping software like Kidspiration to encourage critical thinking. But I do not know how to use it in my Arabic language classroom. I do need some training to practice such application

Looking at the results for the third research question, we can tell that these teachers' use of IWB is very modest: of 179 participants, 153 (85.5\%) reported that they do not use IWB at all. In addition, the use of IWB for substantial learning and teaching activities by the small group of users $(14.5 \%)$ is modest in scope: they concentrate on using IWB as a visual support to demonstrate and present their or students' work, not as an integral tool that leads to radical changes in teaching and learning of Arabic language. This situation could be explained in two ways. Firstly, the average pre-service Arabic language teacher uses the tools he or she believes will make his or her work easier and which require less time to master. This means they choose not to use the features that need more effort and time even if it may have a large impact on teaching and learning process. The other possible reason is the lack of pedagogical skills in using other tools such as the record feature, flip chart and concept-mapping software. It was evident in participants' responses that participants do not have problems in understanding how to use IWB, but how to use these tools effectively to achieve their goals was problematic.

The fourth research question in the present study aimed to identify teachers' perceptions of barriers and challenges in using IWB. The 179 participants were asked to rate 16 potential inhibitors from using IWB as follows: Not an inhibitor at all (1); Not an inhibitor (2); Neutral (3); Inhibiting (4); Highly Inhibiting (5). The findings for this question were divided into two parts: challenges identified by the 153 nonusers of IWB, and challenges identified by the 26 IWB users.

The overall mean scores of non-users ranged between 2.04 and 4.73 . The top five challenges and barriers as indicated by these non-users were (1) dearth of IWBs at schools; (2) deficiency of knowledge and skills in IWB integration; (3) lack of time needed for preparation and use of IWB; (4) insufficient support and encouragement; and (5) shortage of training programs.

The least important challenges noted by non IWB users were lack of interest in using technology, and concern about the benefits of IWB in the learning of Arabic language. This finding showed that even non IWB users perceived IWB as a powerful tool in teaching and learning of Arabic, and are interested in using it; however, they should be provided with access to such technology. Schools should seriously make the necessary planning to supply more modern technology; moreover, pre-service teachers should be provided with adequate training to use certain tools. All challenges and barriers in descending mean rank order are presented in Table 4.

Table 4: Challenges and barriers inhibiting non IWB users from using this tool. ( $N=153)$

\begin{tabular}{|l|c|c|}
\hline Potential inhibitor & M & SD \\
\hline dearth of IWB's at schools & 4.73 & 0.73 \\
\hline deficiency of knowledge and skills in IWB integration & 4.69 & 0.77 \\
\hline lack of time needed for preparation and use of IWB & 4.60 & 0.85 \\
\hline
\end{tabular}

Ishtaiwa, F.F. \& Shana, Z. (2011). The use of interactive whiteboard (IWB) by pre-service teachers to enhance Arabic language teaching and learning. Learning and Teaching in Higher Education: Gulf Perspectives, 8(2). 


\begin{tabular}{|l|l|l|}
\hline insufficient support and encouragement & 4.52 & 0.79 \\
\hline shortage of training programs & 4.49 & 0.86 \\
\hline difficulty in taking students to the IWB classrooms (access to IWB classrooms) & 4.43 & 0.93 \\
\hline curricular barriers & 4.41 & 0.95 \\
\hline lack of time to learn about the use of IWB & 4.31 & 1.16 \\
\hline technical difficulties and failure in the classroom & 4.28 & 1.23 \\
\hline lack of technical support in solving technology problems & 4.25 & 1.17 \\
\hline lack of resources about how to apply IWB in teaching & 3.95 & 1.41 \\
\hline fear of using IWB & 3.77 & 1.41 \\
\hline lack of rewards/recognition for innovation in IWB use & 3.49 & 1.41 \\
\hline lack of students' interest in using technology & 2.69 & 1.29 \\
\hline lack of my interest in using technology & 2.10 & 1.09 \\
\hline concern about the benefits of IWB in the learning of Arabic & 2.04 & 1.07 \\
\hline
\end{tabular}

As shown in Table 5, the overall mean scores of IWB users' perceptions of challenges in employing IWB ranged between 1.15 and 4.53.The top five challenges as indicated by 26 IWB users were: (1) lack of time for preparing and using of IWB; (2) shortage of training programs; (3) deficiency of knowledge and skills in IWB integration; (4) difficulty in accessing IWB classrooms; and (5) lack of resources on IWB application in teaching.

During the interviews many pre-service teachers indicated that time constraints were the most common barrier they encountered when integrating IWB in their classes. They agreed that planning to use IWB required much more time and effort than doing traditional teaching. For example, a participant concluded that

lack of time restricted my implementation of IWB in teaching Arabic. Preparation of IWB required plenty of time. Sometimes I spent two to three hours looking for a good video clip or trying to create a nice presentation. Besides, I wasted a lot of time learning how some features and applications work.

This conclusion leads us to another important challenge that affected the integration of IWB, which is lack of knowledge and skills to integrate IWB effectively in teaching Arabic. Teachers also noted the importance of providing them with training programs to help them integrate IWB effectively. It was interesting to note that 10 interviewees (83\%) indicated that they saw IWB for the first time in their practicum schools. A male participant said:

IWB is an amazing tool of teaching but it is scary at the same time, it is a very complicated device.

Another said:

Before asking me to use it, you should teach me how to deal with something I never saw before.

The analysis of responses to the questionnaire and interview questions thus revealed that these preservice teachers did not perceive lack of rewards/recognition for innovation in IWB use, lack of interest, and concern about the benefits of IWB as the main issues to prevent them from integrating IWB in their classes. So, it can be concluded based on the pre-service teachers' self-evaluations that they are willing

Ishtaiwa, F.F. \& Shana, Z. (2011). The use of interactive whiteboard (IWB) by pre-service teachers to enhance Arabic language teaching and learning. Learning and Teaching in Higher Education: Gulf Perspectives, 8(2). 
to use IWB if they have access to suitable technological tools and resources, and if they are given adequate time, preparation, and training.

Table 5: Challenges and barriers faced by IWB users. $(\mathrm{N}=26)$

\begin{tabular}{|l|c|c|}
\hline Variable & M & SD \\
\hline Lack of time needed for preparation and use of IWB & 4.53 & 0.90 \\
\hline Shortage of training programs & 4.46 & 0.76 \\
\hline Deficiency of knowledge and skills in IWB integration & 4.42 & 0.70 \\
\hline Difficulty in taking students to the IWB classrooms (access to IWB classrooms) & 4.34 & 0.74 \\
\hline Lack of resources about how to apply IWB in teaching & 4.15 & 1.00 \\
\hline Lack of technical support in solving technology problems & 4.03 & 0.82 \\
\hline Lack of time to learn about the use of IWB & 3.96 & 1.42 \\
\hline Technical difficulties and failure in the classroom & 3.69 & 1.51 \\
\hline Insufficient support and encouragement & 3.53 & 1.33 \\
\hline Curricula barriers & 3.5 & 1.30 \\
\hline Dearth of IWBs at schools & 3.07 & 1.35 \\
\hline Fear of using IWB & 1.80 & 1.05 \\
\hline Lack of rewards/recognition for innovation in IWB use & 1.65 & 1.09 \\
\hline Lack of my interest in using technology & 1.46 & 0.90 \\
\hline Lack of students' interest in using technology & 1.30 & 0.83 \\
\hline Concern about the benefits of IWB in the learning of Arabic & 1.15 & 0.36 \\
\hline
\end{tabular}

\section{Conclusion and recommendations}

Realizing that teaching and learning will not be changed by technology itself, but by the way it is incorporated into instruction, will certainly be a critical element in its integration process. The present study aimed to find out how pre-service teachers in UAE schools integrate IWB into their teaching techniques. In addition, the study aimed to examine their perceptions of the impact of using such technology in Arabic teaching and learning during their practicum sessions.

Four main conclusions may be drawn from our findings. Firstly, pre-service Arabic language teachers' integration of technology into their practice depends on their technological competencies and expertise, which means the higher competency they possess, the more integration of technology they will have in classes. Secondly, as indicated by those teachers who had the opportunity to implement IWB during their practicum, IWB is a new technical device that can be used to enhance the teaching and learning of Arabic language in terms of presentation and learning materials; explanation of concepts and ideas; facilitation of learning activities, students' interaction and motivation; and students' achievement and performance.

Ishtaiwa, F.F. \& Shana, Z. (2011). The use of interactive whiteboard (IWB) by pre-service teachers to enhance Arabic language teaching and learning. Learning and Teaching in Higher Education: Gulf Perspectives, 8(2). 
Thirdly, pre-service Arabic language teachers hold positive perceptions of the impact of IWB on the teaching and learning process; however, their perceptions concentrated on making use of IWB as merely a visual support for their instruction which does not contribute to the creative learning and teaching of Arabic language. Finally, all participants including IWB users and non-users showed willingness to increase the integration of IWB in their classes to improve Arabic language teaching and learning. However, there are a number of issues that need to be addressed for more IWB integration such as time, technological infrastructure and resources, training, and technical support.

Based on the findings of the research questions, several recommendations may be offered in order to achieve better IWB integration in Arabic language teaching and learning. First of all, teacher education programs should provide pre-service teachers with the opportunity to familiarize themselves with various technology applications, share ideas and collaborate with each other on new technology projects and uses. This includes infusing technology with pedagogy to ensure that pre-service teachers are equipped with the proper resources and technical skills, and that they have a clear understanding of how this can be integrated effectively within whole-class lessons.

In addition, enhancing the integration of IWB in schools requires a ready access to technology resources and ongoing support. Schools should provide teachers with adequate, reliable, and modern technologies and technical infrastructure that support effective teaching and learning. Training programs for preservice Arabic teachers are also recommended to improve their IWB integration skills; and it is highly recommended that pre-service teachers be rewarded or motivated to use IWB in order to enhance the level of effective technology integration in UAE schools. Addressing the challenges that prevent preservice teachers from integrating IWB will encourage more IWB integration to promote Arabic language teaching and learning.

Finally, this study has made some contribution to the research literature related to IWB. However there is a need for further research to investigate other issues, such as the impact of IWB integration on learners' Arabic language proficiency, students' attitudes towards IWB, types of training programs preservice teachers need, as well as the ways educators can provide for pre-service teachers to link technology and pedagogy.

\section{References}

Ajayi, L. (2009). An Exploration of pre-service teachers' perceptions of learning to teach while using asynchronous discussion board. Educational Technology \& Society, 12(2), 86-100.

Almekhlafi, A. (2006). The effect of computer-assisted language learning (CALL) on United Arab Emirates EFL school students' achievement and attitude. Journal of Interactive Learning Research, 17(2), 121-142.

Březinova, B. (2009). Interactive whiteboard in teaching English to young learners. Master's thesis. Retrieved from http://is.muni.cz/th/105084/pedf_m/interactive_whiteboard_in_teaching_english_to_young_learners.pdf

BECTA (2003). What research says about interactive whiteboards. Coventry, UK: BECTA. Retrieved from http://www.ttrb.ac.uk/ViewArticle2.aspx?Contentld=12434

Brown, S. (2009). Interactive whiteboards in education. Retrieved December, 14, 2010 from http://www.jisc.ac.uk/uploaded_documents/Interactivewhiteboards.pdf

Campbell, C. (2010). Interactive whiteboards and the first year experience: Integrating IWBs into preservice teacher education. Australian Journal of Teacher Education, 35(6).

Ishtaiwa, F.F. \& Shana, Z. (2011). The use of interactive whiteboard (IWB) by pre-service teachers to enhance Arabic language teaching and learning. Learning and Teaching in Higher Education: Gulf Perspectives, 8(2). 
Chen, J., Belkada, S. \& Okamoto, T. (2004). How a web based course facilitates acquisition of English for academic purposes. Language Learning \& Technology, 8 (2), 33-49. Retrieved November 28, 2010 from: http://It.msu.edu/vol8num2/chen/default.html

Crystal, D. (2001). Language and the internet. Cambridge: Cambridge University Press.

Dhindsa, H. S., \& Emran, S. H. (2006). Use of the interactive whiteboard in constructivist teaching for higher student achievement. Proceedings of the Second Annual Conference for the Middle East Teachers of Science, Mathematics, and Computing (pp. 175-188), Abu Dhabi.

Fulton, K., Glenn, A. \& Valdez, G. (2004). Teacher education and technology: Planning guide. Paper presented at the North Central Regional Educational Laboratory with funds from the Institute of Education Sciences (IES), U.S. Department of Education. Naperville, IL: Learning Point Associates. Retrieved November 25, 2010 from: http://www.learningpt.org/pdfs/tech/guide.pdf

Gatlin, M. (2004). Interactive whiteboard system creates 'Active Classrooms' for rural Georgia school system. Technological Horizons in Education Journal, 31(6), 50. Retrieved November, 10, 2010 from: http://www.questia.com/googleScholar.qst?docld=5002074923

Glover D., \& Miller, D. (2001). Running with technology: The pedagogic impact of the large scale introduction of interactive whiteboards in one secondary school. Journal of Information Technology for Teacher Education, 10, 257-276.

Glover, D., \& Miller, D. (2002). The introduction of interactive whiteboards into schools in the United Kingdom: Leaders, led, and the management of pedagogic and technological change. International Electronic Journal for Leadership in Learning, 6(24). Retrieved November 15, 2010, from http://www.ucalgary.ca/iejll/glover_miller

Gray, C., Hagger-Vaughan, L., Pilkington, R., \& Tomkins, S. (2005). The pros and cons of interactive whiteboards in relation to the key stage 3 strategy and framework. Language Learning Journal, 32, 3844.

Hall, I. \& Higgins, S. (2005). Primary school students' perceptions of interactive whiteboards. Journal of Computer Assisted Learning, 21(2), 102-117.

Ishtaiwa, F. (2010). Asynchronous discussion board in the program of Professional Diploma in Teaching: Perceptions of pre-service information technology teachers. International Journal of Arts and Sciences, 3(17), 200-219.

Ismail, S., Almekhlafi, A., \& Al-Mekhlafy, M., (2010). Teachers' perceptions of the use of technology in teaching languages in United Arab Emirates schools. International Journal for Research in Education, 27, 2010.

Johnson, H. (2007). Dialogue and the construction of knowledge in E-learning: exploring students' perceptions of their learning while using blackboard asynchronous discussion board. Retrieved February 28, 2010 from http://www.eurodl.org/materials/contrib/2007/Henry_Johnson.htm.

Kennewell, S. (2001). Interactive whiteboards - yet another solution looking for a problem to solve?. Information Technology in Teacher Education, 39 , 3 - 6.

Kennewell, S. (2006). Reflections on the interactive whiteboard phenomenon: A synthesis of research from the UK. Paper presented at the Australian Association for Research in Education Conference, 26-30 November, Adelaide, Australia.

Ishtaiwa, F.F. \& Shana, Z. (2011). The use of interactive whiteboard (IWB) by pre-service teachers to enhance Arabic language teaching and learning. Learning and Teaching in Higher Education: Gulf Perspectives, 8(2). 
Kern, K. (2006). Perspectives on technology in learning and teaching languages. TESOL Quarterly, 40 (1), 183-210.

Lam, Y. (2000). Technophiliacs, technophobia: A preliminary look at why second- language teachers do or do not use technology in their classrooms. Canadian Modem Language Review, 56(3), 389-420.

Lee, K.W. (2000). English teachers' barriers to the use of computer assisted language learning. The Internet TESL Journal. Retrieved November, 5, 2010 from http://iteslj.org/Articles/Lee-CALLbarriers.html Levy, P. (2002). Interactive whiteboards in learning and teaching in two Sheffield schools: A developmental study. Retrieved November, 14, 2010 from http://dis.shef.ac.uk/eirg/projects/wboards.htm

Mansor, N. (2007). Collaborative learning via email discussion: Strategies for ESL writing classroom. The Internet ESL Journal, 13(3). Retrieved November, 16, from http://iteslj.org/Techniques/MansorEmailDiscussion/

Miles, M. \& Huberman, A. (1994). Qualitative data analysis: An expanded Sourcebook (2 ${ }^{\text {nd }}$ ed.). Thousand Oaks, CA: Sage.

Molebash, P. (2004). Pre-service teacher perceptions of a technology-enrich methods course. Contemporary Issues in Technology and Teacher Education, 3(4), 412-432.

Schuck, S. \& Kearney, M. (2007). Exploring pedagogy with interactive ihiteboards: A case study of six schools. Retrieved February 19, 2010 from http://www.eddev.uts.edu.au/teachered/research/iwbproject/pdfs/iwbreportweb.pdf

Schellens, T., Van Keer, H. \& Valcke, M. (2005). The impact of role assignment on knowledge construction in asynchronous discussion groups. Small Group Research, 36(6), 704-745.

Smith, A. (2000). Interactive whiteboard evaluation. Retrieved November 25, 2010 from http://www.mirandanet.ac.uk/pubs/smartboards.htm

Smith, F., Hardman, F., \& Higgins, S. (2006). The impact of interactive whiteboards on teacher-pupil interaction in the national literacy and numeracy strategies. British Educational Research Journal, 32(3), 443-457.

Swan, K., Schenker, J. \& Kratcoski, A. (2008). The effects of the use of interactive whiteboards on student achievement. In J. Luca \& E. Weippl (Eds.), Proceedings of World Conference on Educational Multimedia, Hypermedia and Telecommunications 2008 (pp. 3290-3297). Chesapeake, VA: AACE.

Timucin, M. (2006). Implementing CALL in the EFL context. ELT Journal, 60(3), 262-271.

Winzenried, A., Dalgarno, B. \& Tinkler, J. (2010). The interactive whiteboard: A transitional technology supporting diverse teaching practices. Australasian Journal of Educational Technology, 26(4), 534-552

Zittle, F. J. (2004). Enhancing native American mathematics learning: The use of smartboard-generated virtual manipulatives for conceptual understanding. Retrieved October 21, 2010 from http://edcompass.smarttech.com/NR/rdonlyres/3E2A063B-6737-400F-BD07-

1D239C428729/0/Zittle.pdf

Ishtaiwa, F.F. \& Shana, Z. (2011). The use of interactive whiteboard (IWB) by pre-service teachers to enhance Arabic language teaching and learning. Learning and Teaching in Higher Education: Gulf Perspectives, 8(2). 